IRA-International Journal of Management \&

Social Sciences

ISSN 2455-2267; Vol.17, Issue 02 (Q.2 2021)

Pg. no. 71-80.

IRA Academico Research

\title{
Analysis of Competitive Strategies of Tourism Industry in the Midst of Covid- 19 Pandemic: A Case from Philippines
}

\author{
Fhrizz S. De Jesus PhD"1\# (i), Annalene Grace E. Co PhD² (i), Czarina P. Zolete ${ }^{3}$ (i) \\ ${ }^{1,3}$ Nueva Ecija University of Science and Technology Atate Campus, Palayan City. Philippines. \\ ${ }^{2}$ Quirino State University, Quirino, Philippines
}

\#corresponding author

Type of Work: Peer Reviewed.

DOI: https://dx.doi.org/10.21013/jmss.v17.n2.p7

How to cite this paper:
Fhrizz S. De Jesus et al. (2021). Analysis of Competitive Strategies of Tourism Industry in the Midst of
Covid-19 Pandemic: A Case from Philippines. IRA-International Journal of Management \& Social Sciences
(ISSN 2455-2267), 17(2), 71-80. DOl: https://dx.doi.org/10.21013/jmss.v17.n2.p7

(C) Authors.

(cc) BY-NC

This work is licensed under a Creative Commons Attribution-NonCommercial 4.0 International License subject to a proper citation to the publication source of the work.

Disclaimer: The scholarly papers as reviewed and published by IRA Academico Research are the views and opinions of their respective authors and are not the views or opinions of IRA Academico Research. IRA Academico Research disclaims any harm or loss caused due to the published content to any party.

IRA Academico Research is an institutional publisher member of Publishers International Linking Association Inc. (PILA-CrossRef), USA. IRA Academico Research is an institutional signatory to the Budapest Open Access Initiative. Hungary advocating the open access of scientific and scholarly knowledge. IRA Academico Research is a registered content provider under Open Access Initiative Protocol for Metadata Harvesting (OAI-PMH).

The journal is indexed \& included in WorldCat Discovery Service (USA), CrossRef Metadata Search (USA), WorldCat (USA), OCLC (USA), Open J-Gate (India), EZB (Germany) Scilit (Switzerland), Airiti (China), Bielefeld Academic Search Engine (BASE) of Bielefeld University, Germany, PKP Index of Simon Fraser University, Canada. 


\section{ABSTRACT}

This study described the Analysis of Competitive Strategies and Challenges of Tourism Industry in the Midst of Covid-19 Pandemic and provide recommendations. Specifically, it looked into the challenges and recommendations of the owners of operational tourist spots in the selected municipalities in Nueva Ecija which are Bongabon and Laur and analyzed how comparative strategies contribute to the challenges and recommendations of the owners of operational tourist spots. This study used the descriptive-evaluative method and total enumeration for its sampling procedure. As to its findings, to improve the tourism operation of the respondents amidst the covid-19 pandemic, the result shows that the respondents "always" used competitive strategies in their businesses. Based on the result, the focus-strategy which is one of the elements of comparative strategies was ranked number one, it means that the owners of operational tourism spots wanted to take all the challenges they were encountered amidst pandemic, it is not a barrier for them to stop their businesses that is why they want to know in a market due to their pleasing tourist spots compared to its competitors and they have recommendations on how to innovate and improve their operational tourist spots.

\section{Keywords: Comparative Strategies, Tourism Industry, Operational Tourist spots}

\section{INTRODUCTION}

The travel and tourism industry is one of the first sectors to be affected by COVID-19. The entire value chain that defines the industry has been inactive since March including airlines, bus and train companies, cruise ships, hotels, restaurants, attractions, travel agents, tour operators, online travel entities, and others. Although the effects of the crisis have been widely documented, the effects of the crisis are perhaps most acutely felt by the Small and Mediumsized Enterprises (SMEs), which account for about $80 \%$ of licensed tourism and tourism-related businesses and are the most vulnerable to failure. Millions of people around the world, including many poor communities that depend on tourism for a living, are at risk of losing their jobs as a result of their possible failure. As many as 100 million jobs supported by travel and tourism are currently at risk [1].

The COVID-19 pandemic will certainly have a major impact on the travel and tourism industry's structure. Many smaller travel and tourism businesses have had to close due to dwindling customer demand, low cash reserves, and a lack of access to flexible credit lines. Although larger companies including national airlines, tour operators, cruise lines, and nationally branded hotel operators are better positioned to withstand the crisis, they are also facing major challenges because demand is unlikely to rebound anytime soon. However, some agile players have repurposed their offerings; the pandemic is expected to drive consolidation and possibly vertical integration across the industry. While in short term, there is a possibility of widespread discounting to attract visitors, the medium to long-term consolidation may spur price increases and reductions in the range and quality of services. As a result, the travel and tourism industry will definitely be smaller than it was before the pandemic, both in terms of jobs and revenue. Consolidation and vertical integration are also likely to limit the opportunities available to operators from developing countries in the market.

Tourism is one of the world's major economic sectors [2]. Tourism is one of the most affected industries by the Covid-19 pandemic, which has had an impact on economies, livelihoods, public services, and opportunities across the globe. The company's entire value chain has been impacted. Considering the high uncertainty about the duration of the pandemic in different parts of the region, and associated contingency and subsequent relaxation measures, it is difficult to estimate the short, medium and long-term impacts of the pandemic on tourism.

With the above statement, the researchers used competitive strategies analysis in Tourism Industry to know what are the challenges and recommendations of the respondents amidst the Covid-19 pandemic.

\section{Conceptual /Theoretical Framework}

This study was based on "Analysis of Competitive Strategies of Tourism Industry in the Midst of Covid-19 Pandemic" this study is from Hospitality and Tourism Industry Amidst Covid-19 pandemic: Perspective on Challenges and Learning from India by Vikrant and Sidharth (2021) which stated that the major implications of the study are in the form of determining themes adding to the evolving theory on Covid-19 pandemic and tourism industry, and managerial recommendations to address a host of issues while taking essential learning stemming from the current circumstances. This study analyzes what competitive strategies used by the owners of the different tourist spots in the selected municipality in Nueva Ecija which is Laur and Bongabon. This paper identifies and analyzes 
that respondents have strategies when it comes to managing their own business especially there is a virus that affects the said businesses, that is why this paper suggest that the respondents should know when they are conducting a strategy that will apply on their business to be successful, they should exert more efforts and should focus on managing their own business.

Additionally, this study was used competitive strategies to achieve through the strategic management of resources, capabilities, and core competencies, as well as the firm's responsiveness to opportunities and threats in the external environment. Strategy matters because it provides directions to a firm. A competitive strategy is a set of decisions necessary to support organizational goals within a specific business. By implementing a certain competitive strategy, a firm defines its position relative to its rivals, which in turn contributes to a competitive advantage. According to Pisano and Hitt (2012), the necessity to embark upon work on competitive strategy is justified by the huge evolution that is characterizing firms' competitive environments since the time Michael Porter elaborated one of the first and more well-known business strategies clarifications.

Therefore, the purpose of this study is to determine the advance such as strategies and to have analysis regarding the Tourism Industry on the selected municipality of Nueva Ecija during the Covid-19 pandemic up to the new normal state.

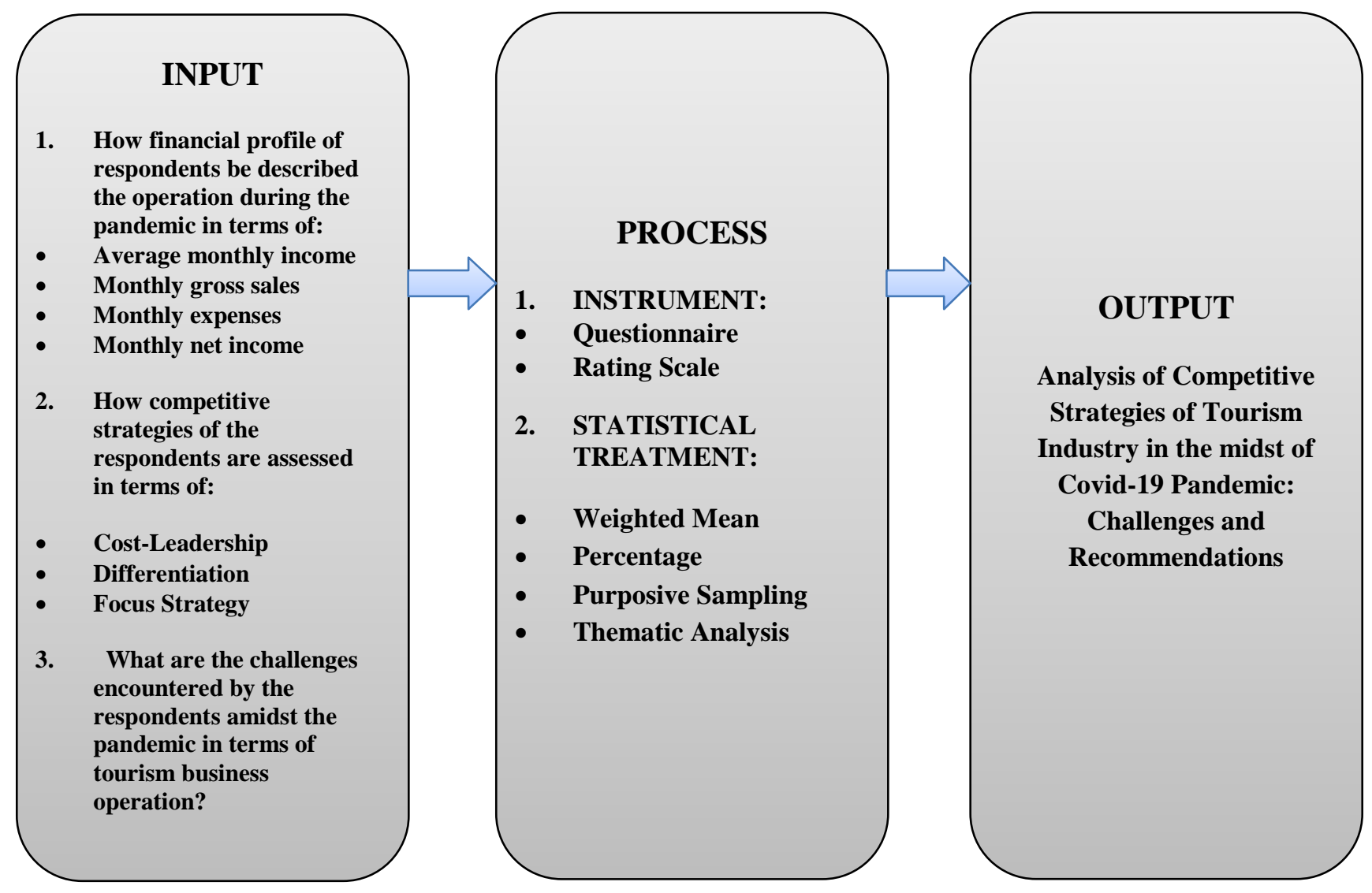

Figure 1.Paradigm of the Study

Figure 1 presents the Paradigm of the Study which includes Input-Process-Output. The input phase includes the socio-demographic profile such as average monthly income, monthly gross sales, monthly expenses and monthly net income and also it includes the competitive strategies which are the cost-leadership, differentiation and focus strategy. In addition, it includes two open-ended questions. 
The process phase contains instrument and statistical treatment, under the instrument there are questionnaire and rating scales, and under the statistical treatment, there are weighted mean, percentage and purposing sampling.

Lastly, for the output phase, the researchers present the Analysis of Competitive Strategies of Tourism Industry in the Midst of Covid-19 Pandemic: Challenges and Recommendations.

\section{METHODOLOGY}

\section{Research Design}

This study used is under the quantitative research design. Qualitative and descriptive research methods have been very common procedures for conducting research in many disciplines, including education, psychology, and social sciences[3]. Specifically, the researchers adopt the method of survey, which is defined as the collection of information from a sample of individuals through their responses to questions [4]. It is a fact-finding study with adequate and accurate interpretation of the findings. This study used the percentage and frequency distribution tool and weighted mean for the interpretation of data.

\section{Study Locale}

This research study was conducted in the municipalities of Bongabon and Laur in the province of Nueva Ecija. Bongabon City is a second-class town comprising 28,000 hectares of farmland, residential and business zones, and forests. Bongabon's tourism office now places the number of visitors to the mountain at 2,000 daily [5]. Laur, formally the Municipality of Laur, is a third-class municipality in the Philippines' Nueva Ecija province, in the Central Luzon area. Laur Nueva Ecija tourist spot - Flying all night to help you fresh sites, on the whole, happens to be impressive and even, a little bit, mind-boggling [6].

\section{Participant Selection}

This study used Total/ Complete enumeration as a method of gathering data. Complete enumeration is a study of every unit, everyone or everything, in a given population [7]. It is also known as complete enumeration, which means a complete count. The researcher used this sampling method as the total number of respondents was feasible for the researcher to get accurate data and information.

\section{Data Collection}

The research instruments used the online survey method, online focus group discussion, and online interview. The distribution of the questionnaire was administered through Google form by the researchers. The questionnaire formulated through the gathered information and checked by the researcher's mentors. The researchers conducted a dry run to check the reliability and validity of the formulated questionnaire. The reliability coefficient of the instrument tested and measured to check the internal consistency. The validity of the research instrument established by presenting the developed research instrument for the comments of the experts who together rated the instrument with a 4.64 weighted mean with a verbal interpretation of "very good".

\section{Data Analysis}

The data collected from the locale were encoded, tallied, and analyzed. Statistical tools such as Percentage, Frequency Distribution, Weighted Mean, and Thematic Analysis were used in analyzing the data gathered.

\section{RESULTS AND DISCUSSIONS}

Relevant questions addressed the profile of respondents in terms of average monthly income, monthly gross sales, monthly expenses and monthly net income.

\section{Profile of the respondents}

Table 1.Profile of the Respondents in Terms Average monthly income

\begin{tabular}{lll}
\hline Average Monthly Income & Frequency & Percentage \\
\hline $\mathbf{5 , 0 0 0 - 1 0 , 0 0 0}$ & 2 & $13 \%$ \\
$\mathbf{1 0 , 1 0 0 - 1 5 , 0 0 0}$ & 4 & $27 \%$ \\
$\mathbf{1 5 , 1 0 0 - 2 0 , 0 0 0}$ & 5 & $33 \%$ \\
$\mathbf{2 0 , 1 0 0 - 3 0 , 0 0 0}$ & 2 & $13 \%$ \\
$\mathbf{3 0 , 1 0 0}$ and above & 2 & $13 \%$ \\
Total & $\mathbf{1 5}$ & $\mathbf{1 0 0 \%}$ \\
\hline
\end{tabular}


Table 1 indicates the distribution of the respondents according to their average monthly income. The majority of the respondents are the owners of the operational tourist spots in Bongabon and Laur Nueva Ecija have an average income that ranges 15,100-20,000 or 33\%. During the pandemic, the income went down because of limited tourists that can visit the place. Based on the respondents, the effects of the pandemic in their business are difficult to handle especially it affects their monthly sales because they need to follow the IATF protocols.

This is consistent with the results, which was showed that reduction in sales has continued for firms. Between July and November 2020, 67 per cent of firms reported a reduction in sales between July and November 2020, compared to 88 per cent between April and July 2020 [8].

Table 2. Monthly Gross Sales

\begin{tabular}{lll}
\hline Monthly Gross Sales & Frequency & Percentage \\
\hline $\mathbf{5 , 0 0 0 - 1 0 , 0 0 0}$ & 1 & $7 \%$ \\
$\mathbf{1 0 , 1 0 0 - 1 5 , 0 0 0}$ & 4 & $27 \%$ \\
$\mathbf{1 5 , 1 0 0 - 2 0 , 0 0 0}$ & 6 & $40 \%$ \\
$\mathbf{2 0 , 1 0 0 - 3 0 , 0 0 0}$ & 1 & $67 \%$ \\
$\mathbf{3 0 , 1 0 0}$ and above & 3 & $20 \%$ \\
Total & $\mathbf{1 5}$ & $\mathbf{1 0 0 \%}$ \\
\hline
\end{tabular}

The table above represents the monthly gross sales of the respondents, and the majority of the answers of the respondents in terms of monthly gross sales fall under $15, \mathbf{1 0 0 - 2 0 , 0 0 0}$ or $40 \%$. Due to the travel restriction, tourismrelated businesses expected to lose their monthly gross sales. According to the respondents because of the restrictions, they have chosen to limit the tourists who will enter their business which resulted in lowered monthly gross sales.

Given the travel restrictions and closure of businesses, $88 \%$ of the respondents expect losses of over $50 \%$ of their 2020 revenues [9].

Table 3. Monthly Expenses

\begin{tabular}{lll}
\hline Monthly Expenses & Frequency & Percentage \\
\hline $\mathbf{5 , 0 0 0 - 1 0 , 0 0 0}$ & 8 & $53 \%$ \\
$\mathbf{1 0 , 1 0 0 - 1 5 , 0 0 0}$ & 6 & $40 \%$ \\
$\mathbf{1 5 , 1 0 0 - 2 0 , 0 0 0}$ & 1 & $67 \%$ \\
$\mathbf{2 0 , 1 0 0 - 3 0 , 0 0 0}$ & 0 & $0 \%$ \\
$\mathbf{3 0 , 1 0 0}$ and above & 0 & $0 \%$ \\
Total & $\mathbf{1 5}$ & $\mathbf{1 0 0 \%}$ \\
\hline
\end{tabular}

Table 4 shows that most of the owners of operational tourist spots in Laur and Bongabon Nueva Ecija have expenses of 5,000-10,000 or 53\%. Based on the respondents, Bongabon and Laur tourism expenditure has seen a large decrease in outbound tourism because of the decreasing residents who were visiting their operational tourist spot.

Export revenues from tourism could fall by $\$ 910$ billion to $\$ 1.2$ trillion in 2020 . This will have a wider effect and could reduce global GDP by $1.5 \%$ to $2.8 \%$ [2].

Table 4. Monthly Net Income

\begin{tabular}{lll}
\hline Monthly Net Income & Frequency & Percentage \\
\hline $\mathbf{5 , 0 0 0 - 1 0 , 0 0 0}$ & 2 & $13 \%$ \\
$\mathbf{1 0 , 1 0 0 - 1 5 , 0 0 0}$ & 7 & $47 \%$ \\
$\mathbf{1 5 , 1 0 0 - 2 0 , 0 0 0}$ & 3 & $20 \%$ \\
$\mathbf{2 0 , 1 0 0 - 3 0 , 0 0 0}$ & 2 & $13 \%$ \\
$\mathbf{3 0 , 1 0 0}$ and above & 1 & $67 \%$ \\
Total & $\mathbf{1 5}$ & $\mathbf{1 0 0 \%}$ \\
\hline
\end{tabular}


The majority of the respondents have a monthly net income of 10,100-15,000 or $47 \%$. The tourism industry has lower monthly net income during a pandemic because of the restrictions. The respondents stated their monthly net income range at 10,100-15,000 because visitors are limited to come to their tourist spots.

The Philippine economy has moved to the recovery stage, but micro, small, and medium-sized enterprises (MSMEs) are continuing to confront a sharp drop in demand and revenue [10]. The strict lockdown in the high-risk provinces lasted from mid-March to the end of May 2020, resulting in massive economic losses.

\section{Competitive strategies of the respondents}

Based on the result below, the "entrance fee and other service fees are affordable yet economical and of good value" was ranked number one with a weighted mean of 4.00 and verbally interpreted as always.

The result indicates that entrance fees and other service fees are affordable yet economical and of good value to help the owners to sustain their business amidst COVID-19. However, due to the restrictions including the IATF Protocols, businesses affect their operation because they only have limited activities and time to undertake. They need self-motivated persistence to acquire knowledge and competencies in order to expand their skills and develop their future opportunities for the benefit of their business. The respondents said, those tourists are easily attracted when they have affordable fees yet economical and of good value.

Table 5. Cost-Leadership

\begin{tabular}{|c|c|c|c|c|}
\hline COST-LEADERSHIP & W.M & VI & RANK & VD \\
\hline $\begin{array}{l}\text { 1. Entrance fee and other service fees are } \\
\text { affordable yet economical and of good value. }\end{array}$ & 4.00 & ALWAYS & 1 & $\begin{array}{l}\text { The statement was } \\
\text { practiced all the time }\end{array}$ \\
\hline 2. Services are consistent and standardized. & 3.77 & ALWAYS & 4 & $\begin{array}{l}\text { The statement was } \\
\text { practiced all the time }\end{array}$ \\
\hline $\begin{array}{l}\text { 3. Embraces advanced technology in their } \\
\text { industry. }\end{array}$ & 3.69 & ALWAYS & 5 & $\begin{array}{l}\text { The statement was } \\
\text { practiced all the time }\end{array}$ \\
\hline 4. Operates continuously. & 3.67 & ALWAYS & 6 & $\begin{array}{l}\text { The statement was } \\
\text { practiced all the time }\end{array}$ \\
\hline 5. Easy and accessible location. & 3.86 & ALWAYS & 3 & $\begin{array}{l}\text { The statement was } \\
\text { practiced all the time }\end{array}$ \\
\hline $\begin{array}{l}\text { 6. Continuously seeks opportunities to } \\
\text { reduce prices without sacrificing the quality } \\
\text { of the services. }\end{array}$ & 3.87 & ALWAYS & 2 & $\begin{array}{l}\text { The statement was } \\
\text { practiced all the time }\end{array}$ \\
\hline Cost-Leadership & 3.83 & ALWAYS & & $\begin{array}{l}\text { The statement was } \\
\text { practiced all the } \\
\text { time }\end{array}$ \\
\hline
\end{tabular}

Consumers see low prices simply as good deals. What shoppers consider when deciding whether or not to purchase a commodity influence their view of a low price [11].

Table 6 below shows that "offering customers a new spot or attraction within the area is eye-catchy" had a garnered weighted mean of $\mathbf{4 . 0 0}$ with verbally interpreted as always.

The data indicates that it helps the owner of the operational tourist spots if they will offer customers a new spot or attraction within the area because it will attract the customers and there is a possibility to increase their profit. They believe that this idea of offering customers a new spot is their differentiation against their competitors, even though they were experiencing a pandemic, is not a barrier for them to attract more customers to come on their operational tourist spots.

However, the connection with the above statement, differentiation strategy approach business develops by providing customers with something unique which is the offers of the customer into a new spot, they are wanted to different and distinct from items of their competitors. Differentiation is an essential marketing process that is of vital economic importance to a business [12]. 
IRA-International Journal of Management \& Social Sciences

Table 6. Differentiation

\begin{tabular}{|c|c|c|c|c|}
\hline DIFFERENTIATION & W.M & VI & RANK & VD \\
\hline $\begin{array}{l}\text { 1. Offers services that are different from its } \\
\text { competitors. }\end{array}$ & 3.93 & ALWAYS & 2 & $\begin{array}{l}\text { The statement was } \\
\text { practiced all the time }\end{array}$ \\
\hline $\begin{array}{l}\text { 2. Offer customers a new spot or attraction } \\
\text { within the area that is eye-catchy. }\end{array}$ & 4.00 & ALWAYS & 1 & $\begin{array}{l}\text { The statement was } \\
\text { practiced all the time }\end{array}$ \\
\hline $\begin{array}{l}\text { 3. Ensures that there is a close relationship } \\
\text { between the customers and the staff }\end{array}$ & 3.80 & ALWAYS & 4.5 & $\begin{array}{l}\text { The statement was } \\
\text { practiced all the time }\end{array}$ \\
\hline $\begin{array}{l}\text { 4. Communicates the points in their spots in } \\
\text { credible ways }\end{array}$ & 3.80 & ALWAYS & 4.5 & $\begin{array}{l}\text { The statement was } \\
\text { practiced all the time }\end{array}$ \\
\hline $\begin{array}{l}\text { 5. Creative and consistent in their area } \\
\text { development }\end{array}$ & 3.70 & ALWAYS & 5 & $\begin{array}{l}\text { The statement was } \\
\text { practiced all the time }\end{array}$ \\
\hline $\begin{array}{l}\text { 6. Ensures constant improvement and use of } \\
\text { innovation to stay ahead of competitors. }\end{array}$ & 3.86 & ALWAYS & 3.5 & $\begin{array}{l}\text { The statement was } \\
\text { practiced all the time }\end{array}$ \\
\hline $\begin{array}{l}\text { 7. Constantly innovate services to create } \\
\text { value for customers }\end{array}$ & 3.86 & ALWAYS & 3.5 & $\begin{array}{l}\text { The statement was } \\
\text { practiced all the time }\end{array}$ \\
\hline Differentiation & 3.85 & ALWAYS & & $\begin{array}{c}\text { The statement was } \\
\text { practiced all the } \\
\text { time }\end{array}$ \\
\hline
\end{tabular}

Table 7 below shows that most of the respondents believe that their business is well known in the market due to their pleasing tourist spots compared to its competitors, that is why it was ranked number 1 and has a weighted mean of 4.00 with a verbal interpretation of always.

The majority of respondents claimed that being known in other barangays helps their firm expand and improve sales, which allows them to add and innovate their operating tourism attraction.

In connection with the above findings, focus strategy involves targeting products to a niche market or targeted audience. The idea behind focus strategy is developing, marketing and selling products or services to a niche market, such as a particular type of consumer, a specific product line or a targeted geographical area. It involves market segmentation and specialization in the chosen segment which is useful in gaining competitive advantage [13].

Table 7. Focus Strategy

\begin{tabular}{|c|c|c|c|c|}
\hline FOCUS STRATEGY & W.M & VI & RANK & VD \\
\hline $\begin{array}{l}\text { 1. Adopts and responds fast to the } \\
\text { environment's changing needs }\end{array}$ & 3.80 & ALWAYS & 4 & $\begin{array}{l}\text { The statement was } \\
\text { practiced all the time }\end{array}$ \\
\hline 2. Have a strong customer relationship & 3.86 & ALWAYS & 3.5 & $\begin{array}{l}\text { The statement was } \\
\text { practiced all the time }\end{array}$ \\
\hline $\begin{array}{l}\text { 3. Customer complaints are resolved on a } \\
\text { timely basis }\end{array}$ & 3.86 & ALWAYS & 3.5 & $\begin{array}{l}\text { The statement was } \\
\text { practiced all the time }\end{array}$ \\
\hline $\begin{array}{l}\text { 4. Offers price-sensitive solutions towards } \\
\text { the industry's specific needs. }\end{array}$ & 3.73 & ALWAYS & 5 & $\begin{array}{l}\text { The statement was } \\
\text { practiced all the time }\end{array}$ \\
\hline $\begin{array}{l}\text { 5. Attracts more customers using } \\
\text { competitive prices }\end{array}$ & 3.93 & ALWAYS & 2 & $\begin{array}{l}\text { The statement was } \\
\text { practiced all the time }\end{array}$ \\
\hline $\begin{array}{l}\text { 6. It is well known in the market due to their } \\
\text { pleasing tourist spots compared to its } \\
\text { competitors }\end{array}$ & 4.00 & ALWAYS & 1 & $\begin{array}{l}\text { The statement was } \\
\text { practiced all the time }\end{array}$ \\
\hline Focus Strategy & 3.86 & ALWAYS & & $\begin{array}{l}\text { The statement was } \\
\text { practiced all the } \\
\text { time }\end{array}$ \\
\hline
\end{tabular}


Table 8. Challenges Encountered by the Owners of Different Tourist Spots

\begin{tabular}{cccc}
\hline $\begin{array}{c}\text { Challenges Encountered by the Owners of } \\
\text { Different Tourist Spots }\end{array}$ & Frequency & Percentage & Rank \\
\hline $\begin{array}{c}\text { Decrease of the number of tourist arrivals } \\
\text { New guidelines that must be followed in } \\
\text { Unstable operation schedule }\end{array}$ & 6 & $40 \%$ & 1 \\
TOTAL & 5 & $33 \%$ & 3 \\
\hline
\end{tabular}

Based on table 8, it can be observed that the "decrease of the number of tourist arrivals" got a frequency of 6 or 40\%. This indicates that due to the pandemic, people are afraid to go outside their houses and visit a tourist destination because of the possible transfer of the virus. Respondents agreed that due to the pandemic, their business operations became unstable.

The pandemic, including global supply chains, is having a major impact on labor markets, economies and businesses, leading to widespread business disruptions [17]. Coronavirus COVID 19 outbreak brought evolving challenges worldwide, one of those affected parts was the tourism industry. COVID 19 created a riskier situation in the tourism industry. The fact that governments implemented laws including travel restrictions, the tourism industry faced severe despondency among other sectors worldwide. The tourism industry was one of the world's greatest markets; until the world met a pandemic in the 21st century, COVID-19 [14].

The data gathered by the researchers regarding the challenges encountered by the respondents amidst the pandemic in terms of their business operation shows that the decrease in tourist arrivals was the leading challenge to them. This pandemic brought fear and anxiety to everyone, not only because of the restrictions coming from the governments but also because of the terrifying effects of the virus. The fact that there is no present and proven cure to this virus in our country, tourists are still afraid to go outside and travel, that is why customer numbers in the tourist industry decreased. The COVID-19 pandemic has expanded across the world by creating shocks in almost all industries due to the restrictions, curfews, stay-home and work-from-home policies, and quarantines [15].

The decrease in tourist arrivals in the tourist industry also brought a decrease in the business income in which they are challenged on how are they going to cope up and rise again given the situation brought by the COVID 19 pandemic. The tourism industry cost a loss of over US\$ 820 billion in revenue globally due to the COVID-19 pandemic [15]. According to the gathered data, most of the respondents are depending on their cost of living to their tourist business; they have also hired staff to assist in their business operation. The decrease in business income caused by the present pandemic extremely affected the respondents' way of living as well as the staff that lose their jobs. As many as 100 million jobs supported by travel and tourism are currently at risk [1].

Aside from the stated challenges, respondents are also presently challenged on how they continue their business during the pandemic while considering their health safety. COVID 19 is a virus that spreads easily from an infected to a non-infected person if the business owner became infected, the operation of the business is also affected. By that, business owners are challenged on how they continue their businesses while protecting their health safety amidst the present pandemic which is the COVID 19. Working in the absence of protections such as sick leave or unemployment benefits, these workers may need to make a choice between health and income, which comes at a risk to both their health, the health of others and their economic wellbeing [16]. 
IRA-International Journal of Management \& Social Sciences

\section{CONCLUSIONS AND RECOMMENDATIONS}

Conclusions were drawn on the basis of the results which the majority of the respondents were considered as financially stable. Most of them can make a monthly net income of 10,000-15,000 in as much that all expenses are deducted.

Operators always want to grow their business even there are a lot of hindrances to cope with. They "always" analyse the continuously operating of the tourism industry to increase as well their sales amidst pandemic; they prioritize offering customers anew spot or attraction within the area that is eye-catchy which help to generate higher profit as well, and being popular in the market due to their pleasing tourist spots (including the view and other sites) compared to its competitors intend as one of their ways to attract tourist.

The respondents "always" experienced a decrease in the number of tourist arrivals along with decreasing amount of income generation.

It is recommended to the tourist industry strengthen the use of their practices and adopt other best practices to replace their ineffective actions during the COVID-19 pandemic. By doing so, the tourist industry can achieve a more productive field despite the pandemic. Developing new plans proportional to the present pandemic situations will lead to a new strategic direction and digital transformation of tourist industries which may result in the improvement of the services they will provide. It is recommended to use different interventions which are applicable in solving problems encountered by the tourist industry. It may help them in identifying their major challenges and the possible solutions that may contribute to their economic benefits and support them in accelerating and stabilizing economic growth.

\section{References}

[1]. World Travel \& Tourism Council (2021). Safe Travels': Global Protocols \& Stamp for the New Normal. Retrieved from: https://wttc.org/COVID-19/Safe-Travels-Global-Protocols-Stamp

[2]. UN World Tourism Organization 2020). Tourism and Covid-19-Unprecedented Economic Impacts. Retrieved from: https://www.unwto.org/tourism-and-covid-19-unprecedented-economic-impacts

[3]. Nassaji, H. (2015). Qualitative and descriptive research: Data type versus data analysis. Language Teaching Research, 19(2), 129-132. https://doi.org/10.1177/1362168815572747

[4]. Ponto J. (2015). Understanding and Evaluating Survey Research. Journal of the advanced practitioner in oncology, 6(2), 168-171.

[5]. Cajucom, C. M. (2021, February 16). National park in Nueva Ecija's Bongabon town beckons visitors.

Retrieved from: https://www.manilatimes.net/2021/02/16/news/regions/national-park-nueva-ecijas-bongabontown-visitors $/ 841430$

[6]. Ranu, B. (2020, July 31). Laur Nueva Ecija Tourist Spot.

Retrieved from: https://guideyourtrips.blogspot.com/2020/07/laur-nueva-ecija-tourist-spot.html

[7]. Australian Bureau of Statistics (2013). Statistical Language-Census and Sample. Retrieved from: https://www.abs.gov.au/websitedbs/D3310114.nsf/Home/Statistical+Language+-

+census+and+sample\#: : :text=A\%20census\%20is\%20a\%20study,in\%20a\%20population\%20of\%20interest.

[8]. World Bank. (2021). Impacts of COVID-19 on firms in the Philippines. Retrieved from: http://hdl.handle.net/10986/35430

[9]. PwC Philippines (2021, July). Impact of COVID-19 on the Philippine Tourism industry. Retrieved from https://www.pwc.com/ph/en/publications/tourism-pwc-philippines/tourism-covid-

19.html\#: :text=Impact\%20of\%20COVID\%2D19\%20outbreak,50\%25\%20of\%20their\%202020\%20revenues.\& text=Latest\%20estimates\%20show\%20that\%202020,to\%203.9\%20million\%20and\%20PHP279.

[10]. Shinozaki, S., Rao, L., N. (2021, February). COVID-19 Impact on Micro, Small, and Medium-Sized Enterprises under the Lockdown: Evidence from a Rapid Survey in the Philippines. Retrieved from: https://www.adb.org/sites/default/files/publication/677321/adbi-wp1216.pdf

[11]. Business News Daily (2020, March 12). Why Low Price Can Scare Off Customers. Retrieved from: https://www.businessnewsdaily.com/3455-cheap-prices-customers.html

[12]. CFI (2021). Product Differentiation.

Retrieved from: https://corporatefinanceinstitute.com/resources/knowledge/strategy/product-differentiation/

[13]. Onyango, J. (2017), Influence of Cost Leadership, Differentiation And Focus Strategies On Firm Competitiveness: The Case Of Boc Kenya Limited. 
Retrieved from:

http://erepo.usiu.ac.ke/bitstream/handle/11732/3246/JANET+JOAN+ONYANGO+MBA+2017.pdf?sequence=1 \&isAllowes $=\mathrm{y}$

[14]. Uğur, N. G., \& Akbiyık, A. (2020). Impacts of COVID-19 on global tourism industry: A cross-regional comparison. Tourism management perspectives, 36, 100744. https://doi.org/10.1016/j.tmp.2020.100744

[15]. Kumudumali, S., H., T., (10 September 2020), Impact of COVID-19 on Tourism Industry: A Review. Retrieved from: https://mpra.ub.uni-muenchen.de/102834/1/MPRA_paper_102834.pdf

[16]. International Labour Organization, (2020). The COVID-19 pandemic: How is the world of work affected? Retrieved from: wcms_742463.pdf (ilo.org)

[17]. De Jesus, F., \& Buenaventura, B. (2021). IMPACT OF COVID-19 PANDEMIC IN THE SUPPLY CHAIN MANAGEMENT OF THE MILK TEA STORES. The International Journal of Accounting and Business Society, 29(1), 1-14. Retrieved from https://www.ijabs.ub.ac.id/index.php/ijabs/article/view/534 